\title{
An Engineering Approach to Design Perforated and Non Perforated Modified Atmospheric Packaging unit for Capsicum
}

Pandey SK and Goswami T. K*

Department of Agricultural and Food Engineering, Indian Institute of Technology, Kharagpur, India

\begin{abstract}
An engineering approach was used to design a packet containing capsicum under perforated and non perforated packaging conditions. A model combining the Michaelis-Menten kinetics to describe the respiration rate of the product with mass transfer equation to describe the gas transfer across the package provided a good fit to the experimental data. Developed model can be successfully utilized under similar conditions.
\end{abstract}

Keywords: Perforated; Non perforated; Modified Atmosphere; Packaging; Capsicum

\section{Introduction}

The demand of capsicum is high in the market throughout the year whether in household or in hotel industry, internationally, its demand is high in European market. The high demand is due to its varied uses in fresh as well as in cooked form. It has been reported that $70 \%$ of the capsicum produced when reaches market exhibits variety of disorder, mainly due to poor post harvest handling, transport, storage, and marketing practices. Water loss, tissue softening, shriveling, and chilling injury (CI) are the major challenges, which limit the quality and post harvest life of capsicum [1-2].

There are numerous techniques available to reduce the post harvest losses namely controlled atmospheric storage (CAS), modified atmospheric packaging (MAP), refrigeration etc. Out of these technologies available, most widely used technique is MAP, as it provides advantage of low cost and easy implementation at the commercial level. MAP is atmospheric modification due to interplay of respiration process and exchange of gas through the packaging unit. Therefore, MAP is a dynamic system and gets influenced by many factors. Engineering design of MAP system starts from determination of respiration rate, optimal modified atmosphere for commodities combined with the required product filling weight/package area, the recommended gas permeability of the packaging film for $\mathrm{O}_{2}$ and $\mathrm{CO}_{2}$ [3-5]. Engineering approach obviates the need of trial and error approach to get desired in package gaseous concentration. Conducting trial is time consuming and also costly affair. Hence, engineering approach is an alternative that would be more appropriate way to save both cost and time.

Many scientists have reported positive effect of MAP on capsicum. For example, water loss may be significantly reduced by packaging capsicum in plastic films [6-7]. Gonzalez and Tiznado [7] reported $60 \%$ loss of firmness of capsicum within 20 days out of 40 days storage of produce at the temperature of $10^{\circ} \mathrm{C}$, packed in LDPE, whereas significant loss of firmness was noticed in control within 10 days of storage. Additionally, wrapping green capsicums in plastic films contributed to better green-color retention compared to non-wrapped fruit [7-8]. Hence, MAP led to overall high quality produce with increased shelf life.

In the present study, an engineering approach was used to properly design a consumer packet containing capsicum under non perforated and perforated condition of MAP. Developed models were validated under different packaging conditions.

\section{Mathematical consideration}

Target in-package air composition for MAP: Recommended in-package optimal $\mathrm{O}_{2}$ concentration should not be less than $2 \%$ and $\mathrm{CO}_{2}$ concentration should range between $2-5 \%$ for the safe storage, as recommended by Manolopoulou et al. [9].

Consumer packet, sufficient to store 500 gm of capsicum i.e. four in numbers was considered for optimization under different MAP conditions for present study.

\section{Engineering approach in designing of MAP}

Mathematical modeling of gaseous exchange in MAP: There are basically two phenomena at stake in case of perforated modified packaging: respiration and mass transfer through film perforation as shown in (Figure 1). The respiration process involves $\mathrm{O}_{2}$ consumption and $\mathrm{CO}_{2}$ evolution.

Gas exchange through a polymeric film follows Fick's law of diffusion and obeys Eq. (1) as

$$
J_{f i}=\frac{A_{f} P_{f i}}{L_{f}}\left(C_{i}^{\text {out }}-C_{i}^{\text {in }}\right)
$$

where, $C_{i}^{\text {out }}$ and $C_{i}^{\text {in }}$ are the volumetric fraction of gas $\mathrm{i}$ outside and inside the packet, $A_{f}$ is the film area, $L_{f}$ is the thickness of the film, $\mathrm{P}_{\mathrm{f}}$ is permeability of the film. The amount of $\mathrm{O}_{2}$ consumed and $\mathrm{CO}_{2}$ produced in a packet can be obtained as follows:

$\mathrm{O}_{2}$ consumption inside the packet $=\mathrm{M} \mathrm{R}_{02}$

$\mathrm{CO}_{2}$ evolution inside the packet $=\mathrm{M} \mathrm{R}_{\mathrm{co2}}$

where, $R_{o_{2}}$ and $R_{c 0_{2}}$ are the respiration rate of $\mathrm{O}_{2}$ consumption and $\mathrm{CO}_{2}$ production and $\mathrm{M}$ is the mass of the produce.

*Corresponding author: Tridib Kumar Goswami, Department of Agricultural and Food Engineering, Indian Institute of Technology, Kharagpur, India, Tel: +91-3222283123; Fax: +91-3222-282244; E-mail: tkg@agfe.iitkgp.ernet.in

Received August 17, 2012; Accepted August 24, 2012; Published August 30 2012

Citation: Pandey SK, Goswami TK (2012) An Engineering Approach to Design Perforated and Non Perforated Modified Atmospheric Packaging unit for Capsicum. J Food Process Technol 3:187. doi:10.4172/2157-7110.1000187

Copyright: () 2012 Pandey SK, et al. This is an open-access article distributed under the terms of the Creative Commons Attribution License, which permits unrestricted use, distribution, and reproduction in any medium, provided the original author and source are credited. 


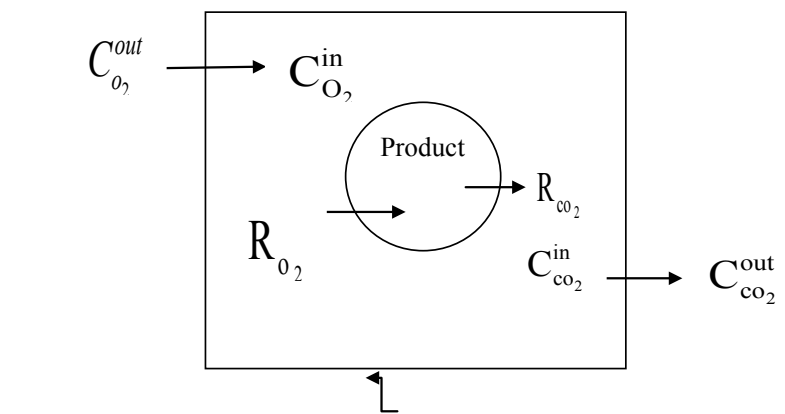

Figure 1: Schematic Presentation of product with non perforated plastic film used for measuring gas exchange phenomena of capsicum.

Applying mass balance across the film, the rate of change of $\mathrm{O}_{2}$ and $\mathrm{CO}_{2}$ inside the packet can be presented through Eqs. (2) and (3) respectively as

$$
\begin{array}{r}
\frac{d C_{0_{2}}}{d t}=\frac{P_{o_{2}} A_{f}}{L_{f} V_{f}}\left(C_{o_{2}}^{\text {out }}-C_{o_{2}}^{i n}\right)-\frac{R_{o_{2}} M}{V_{f}} \\
\frac{d C_{c o_{2}}}{d t}=\frac{P_{c o_{2}} A_{f}}{L_{f} V_{f}}\left(C_{c o_{2}}^{\text {out }}-C_{c o_{2}}^{i n}\right)+\frac{R_{c o_{2}} M}{V_{f}}
\end{array}
$$

where, $\mathrm{C}_{\mathrm{O}_{2}}$ and $\mathrm{C}_{\mathrm{CO}_{2}}$ are the volumetric fraction of $\mathrm{O}_{2}$ and $\mathrm{CO}_{2}$ gases inside the packet (v/v), $\mathrm{t}$ is the time, $\mathrm{h}, C_{\mathrm{O}_{2}}^{\text {out }}$ and $C_{\mathrm{Co}_{2}}^{\text {out }}$ are the volumetric fraction of $\mathrm{O}_{2}$ and $\mathrm{CO}_{2}$ at the ambient condition, $P_{o_{2}}$ and $P_{c o_{2}}$ are the permeability of the film to the $\mathrm{O}_{2}$ and $\mathrm{CO}_{2}$ respectively, $\mathrm{ml} \mathrm{m} \mathrm{m} \mathrm{m}^{-2} \mathrm{~h}^{-1}$ atm $^{-1}, \mathrm{~A}_{\mathrm{f}}$ is the surface area of the film, $\mathrm{m}^{2}, \mathrm{~L}_{\mathrm{f}}$ is the thickness of the film, $\mathrm{m}, R_{O_{2}}$ is the $\mathrm{O}_{2}$ consumption rate of the product, $\mathrm{mlkg}^{-1} \mathrm{~h}^{-1}, R_{c o_{2}}$ is the $\mathrm{CO}_{2}$ production rate of the product, $\mathrm{ml} \mathrm{kg}^{-1} \mathrm{~h}^{-1}$, and $\mathrm{M}$ is the mass of the product in the package, $\mathrm{kg}, \mathrm{V}_{\mathrm{f}}$ is the free volume in the packet, $\mathrm{ml}$.

Mathematical modeling under perforated condition: Getting polymeric film having desired permeability for slow or high respiring produce in bulk is a difficult task. To overcome the problem encountered in continuous film, perforation is another way to increase the gas transmission rate (GTR). In case of perforated modified packaging, there are basically three phenomena at stake: respiration, mass transfer through film and mass transfer through perforation as shown in Figure.2. Porous material is responsible for gaseous exchange with its surroundings. Moreover, if the packaging material is perforated, it will represent an alternative route for gas transpiration in parallel to the packaging material. In this case, the total flow of the gas is given by Eq. (4) as

$$
J_{i}=J_{f i}+J_{h i}
$$

where, $\mathrm{J}_{\mathrm{fi}}$ is the flow of a gas $\mathrm{i}$ across the film and $\mathrm{J}_{\mathrm{hi}}$ is the flow of a gas $\mathrm{i}$ through the holes.

Applying mass balance for the $\mathrm{O}_{2}$ and $\mathrm{CO}_{2}$ gas exchange in a permeable package with perforation, the equations for the volumetric change of $\mathrm{O}_{2}$ and $\mathrm{CO}_{2}$ gases inside a perforated MAP with respiring produce are Eqs. (5) and (6) respectively Pandey and Goswami [10].

$$
\frac{d C_{0_{2}}}{d t}=\frac{n_{p} U_{o_{2}}}{V_{f p}}\left(C_{o_{2}}^{\text {out }}-C_{o_{2}}^{\text {in }}\right)+\frac{P_{o_{2}} A_{f}}{L_{f} V_{f p}}\left(C_{o_{2}}^{\text {out }}-C_{o_{2}}^{\text {in }}\right)-\frac{R_{o_{2}} M}{V_{f p}}
$$

$$
\frac{d C_{c 0_{2}}}{d t}=\frac{n_{p} U_{c 0_{2}}}{V_{f p}}\left(C_{c o_{2}}^{o u t}-C_{c 0_{2}}^{i n}\right)+\frac{P_{c 0_{2}} A_{f}}{L_{f} V_{f p}}\left(C_{c o_{2}}^{\text {out }}-C_{c 0_{2}}^{i n}\right)+\frac{R_{c 0_{2}} M}{V_{f p}}
$$

where, $\mathrm{C}_{\mathrm{O}_{2}}$ and $\mathrm{C}_{\mathrm{CO}_{2}}$ are the volumetric fraction of $\mathrm{O}_{2}$ and $\mathrm{CO}_{2}$ gases inside the container $(\mathrm{v} / \mathrm{v})$, $\mathrm{t}$ is the time, $\mathrm{h}, U_{o_{2}}$ and are the $\mathrm{O}_{2}$ and $\mathrm{CO}_{2}$ effective permeability through the perforation, $\mathrm{cm}^{3} \mathrm{~h}^{-1}$, and $C_{\mathrm{O}_{2}}$ are the volumetric fraction of $\mathrm{O}_{2}$ and $\mathrm{CO}_{2}$ at the ambient condition $(\mathrm{v} / \mathrm{v}), C_{c c_{2}}$ and $P_{c o_{2}}$ are the permeability of the film to the $\mathrm{O}_{2}$ and $\mathrm{CO}_{2}$ respectively, $\mathrm{ml} \mathrm{m} \mathrm{m}^{-2} \mathrm{~h}^{-1} \mathrm{~atm}^{-1}, C_{c_{2}}^{\text {out }}$ is the $\mathrm{O}_{2}$ consumption rate of the product, $\mathrm{mlkg}^{-1} \mathrm{~h}^{-1}, R_{c o_{2}}$ is the $\mathrm{CO}_{2}$ production rate of the product, $\mathrm{ml}$ $\mathrm{kg}^{-1} \mathrm{~h}^{-1}$, and $\mathrm{M}$ is the mass of the product in the package, $\mathrm{kg}, \mathrm{V}_{\mathrm{fp}}$ is the free volume in the packet, $\mathrm{ml}$.

\section{Materials and Methods}

\section{Respiration rate measurement}

Detailed discussion about respiration is provided in the manuscript published by [10]. The coefficients used under Michalis Menten (MM) type equations were also taken from the same manuscript.

\section{Simulation of gas exchange dynamics}

Non-linear differential Eqs. (2) and (3) were solved numerically using MATLAB software with initial concentrations of $\mathrm{O}_{2}$ as $0.21(\mathrm{v} / \mathrm{v})$ and $\mathrm{CO}_{2}$ as $0.0003(\mathrm{v} / \mathrm{v})$. The parameters those influence in attaining steady state condition are mass of the product, area, permeability of the film, and surface area. Eqs. (2) and (3) are useful tool to predict the gaseous exchange over the time for optimization of gaseous conditions for packet design. Eqs. (2) and (3) are simultaneous equations, the solution of these equations would give variable oxygen concentration and carbon dioxide concentration inside the packet with time $\mathrm{dt}, \mathrm{h}$.

\section{Measurement of gas exchange through packet}

After exposing the product for four hours to the desired temperatures, capsicum weighing approximately $500 \mathrm{~g}( \pm 10 \mathrm{gm})$ i.e. four in numbers, were packed in the perforated and non perforated LDPE film $(45 \mu \mathrm{m})$. A sample of $1 \mathrm{ml}$ of headspace gas was drawn from each bag with a calibrated syringe through self-glued septum. Gas exchange was measured with GC. Three replications were performed for each set of experiments and the average is reported.

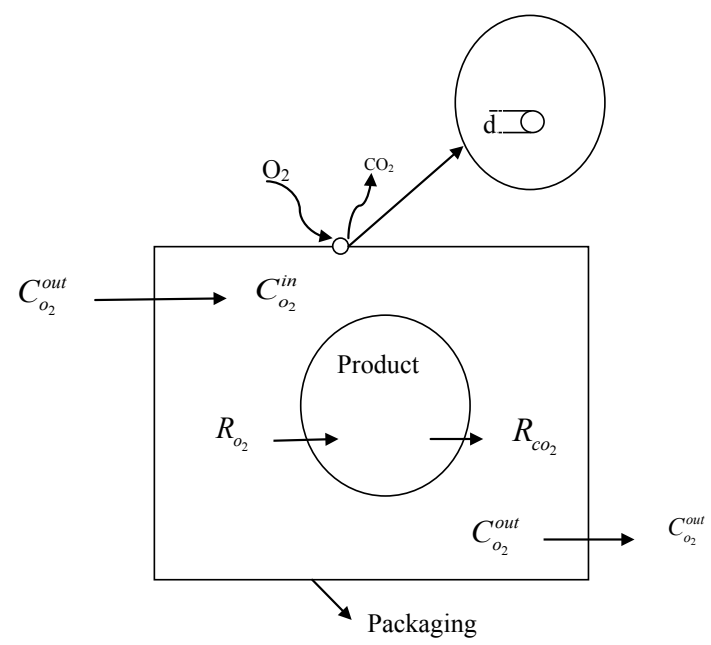

Figure 2: Schematic presentation of mass exchange with the product through perforated plastic film. 


\section{MAP designing under non perforated condition}

At steady state, Eq. (2) is reduced to Eq. (7) as

$$
A P\left(C_{\text {out }}^{i}-C_{\text {in }}^{i}\right)=R W
$$

Optimum gaseous concentration was selected as $4 \% \mathrm{O}_{2}$ and $\mathrm{CO}_{2}$ respectively. By substituting these concentrations in Model 2 [10] respiration rate for $\mathrm{O}_{2}$ consumption was obtained as 4.25 and 8.45 $\mathrm{ml}(\mathrm{kg} \mathrm{h})^{-1}$ at the temperatures of 5 and $15^{\circ} \mathrm{C}$, respectively. MM type equation was used to model the respiration process. With known mass of capsicum weighing $500( \pm 10)$ gm, i.e., with four in numbers was envisaged to be packed in a film having known GTR of 66.21 and $121.84 \mathrm{ml}\left(\mathrm{m}^{2} \mathrm{~h}\right)^{-1}$ at the temperatures of 5 and $15^{\circ} \mathrm{C}$ respectively. The film used here was of LDPE (low density polyethylene), supplied by Reliance industry, Kolkata, of thickness $45 \mu \mathrm{m}$. GTR of the film was determined through a permeability tester (LABTHINK Model, Make, China). Substituting all the known parameters in Eq. (4), optimized area was obtained as $27 \times 35 \mathrm{~cm}$ (with effective area of $0.1890 \mathrm{~m}^{2}$ ) and $27 \times 36 \mathrm{~cm}$ (with effective area of $0.1944 \mathrm{~m}^{2}$ ) at temperatures of 5 and $15^{\circ} \mathrm{C}$ respectively.

\section{MAP designing of packet parameter under perforated condition}

For designing modified atmosphere packet under perforated condition, minimum area for packet size capable of holding $500( \pm 10)$ gm of capsicum i.e. four in numbers was determined as $23 \times 23 \mathrm{~cm}$ as a consumer packet. Perforation diameter was selected as $0.3 \mathrm{~mm}$ based on the available facility and thin needle was used to obtain the desired diameter of perforation. With the known weight of the produce, with one perforation, permeability of the film and with the void volume of $608 \mathrm{ml}$ (determined through water displacement method), gas exchange was recorded till the equilibrium point reached.

\section{Validation of model}

The mean relative percentage deviation modulus was evaluated as criteria for checking the fitting adequacy. The experimental and predicted values were then compared using Eq. (8) to determine the best fit equation Bhande et al. [11]. In general, lower the value of the module better is the agreement between experimental and predicted values.

$$
\mathrm{E}=\left[\frac{100}{\mathrm{~N}} \sum_{\mathrm{i}=1}^{\mathrm{n}} \frac{\left|\mathrm{R}_{\text {exp }}-\mathrm{R}_{\text {pre }}\right|}{\mathrm{R}_{\mathrm{exp}}}\right]
$$

where, $\mathrm{E}$ is the mean relative deviation modulus in \%; $\mathrm{N}$ is the number of respiration data points; $\mathrm{R}_{\exp }$ is the experimental respiration rate in $\mathrm{mlkg}^{-1} \mathrm{~h}^{-1}$ and $\mathrm{R}_{\text {pre }}$ is the predicted respiration rate in $\mathrm{ml} \mathrm{kg}^{-1} \mathrm{~h}^{-1}$.

\section{Results and Discussion}

\section{Validation of the developed model under non perforated condition}

Steady state gaseous exchange under non perforated condition at temperatures of 5 and $15^{\circ} \mathrm{C}$ are shown in Figure. 3. In package steady state $\mathrm{O}_{2}$ and $\mathrm{CO}_{2}$ concentration were recorded as $3.28 \% \mathrm{O}_{2}$ and $3.12 \%$ $\mathrm{CO}_{2}$ at temperature of $5^{\circ} \mathrm{C}$, and $3.14 \% \mathrm{O}_{2}$ and $3.11 \% \mathrm{CO}_{2}$ at $15^{\circ} \mathrm{C}$. At temperature of $5^{\circ} \mathrm{C}$, the packet took around 16 days to reach the equilibrium state while at $15^{\circ} \mathrm{C}$ it attained the steady state after 8 days.

It took nearly 8-12 $\mathrm{h}$ more to attain the steady state than the predicted time.
On validation of model (Eqs. 2 and 3), mean relative deviation moduli E (\%) was recorded as $2.5 \%$ for $\mathrm{O}_{2}$ and $5.29 \%$ for $\mathrm{CO}_{2}$ at temperature of $5^{\circ} \mathrm{C}$. Similarly at $15^{\circ} \mathrm{C}, \mathrm{E}(\%)$ was recorded as $3.02 \%$ for $\mathrm{O}_{2}$ and $3.64 \%$ for $\mathrm{CO}_{2}$. At both the temperatures, model provided good fit to the data obtained, as E value was less than $10 \%$ [11].

\section{Validation of developed model under perforated condition}

Steady state in package $\mathrm{O}_{2}$ and $\mathrm{CO}_{2}$ concentrations were recorded as $12.56 \%$ and $3.78 \%$ at temperature of $5{ }^{\circ} \mathrm{C}$ and $9.98 \%$ and $4.24 \%$ at temperature of $15^{\circ} \mathrm{C}$, respectively. Gas sampling was performed at specific time intervals and analyzed through gas chromatograph (GC). Models (Eqs. 5 and 6) were validated at temperature of 5 and $15^{\circ} \mathrm{C}$ as shown in Figure 4 . Additionally, film took three to four days in establishing the steady state in package gaseous concentration. There was time gap of $4-8 \mathrm{~h}$ in between predicted and actual time to attain the steady state.

While validating, $\mathrm{E}$ values obtained for $\mathrm{O}_{2}$ and $\mathrm{CO}_{2}$ concentration were $1.68 \%$ and $7.53 \%$ at $5{ }^{\circ} \mathrm{C}$ and $1.5 \%$ and $3.95 \%$ at $15^{\circ} \mathrm{C}$ respectively. Thus, the developed model fitted the data well and can be successfully utilized under such condition, as $\mathrm{E}$ values were less than $10 \%$. Obtained gaseous concentration was well within the range prescribed by [9]. Furthermore, simulation was also done for area of $26 \times 26 \mathrm{~cm}$ at temperature of $5^{\circ} \mathrm{C}$, and the steady state $\mathrm{O}_{2}$ and $\mathrm{CO}_{2}$ concentration were obtained as $13.22 \%$ and $3 \%$ respectively, keeping the void volume constant. This showed that increasing area in case of perforated film

(a)

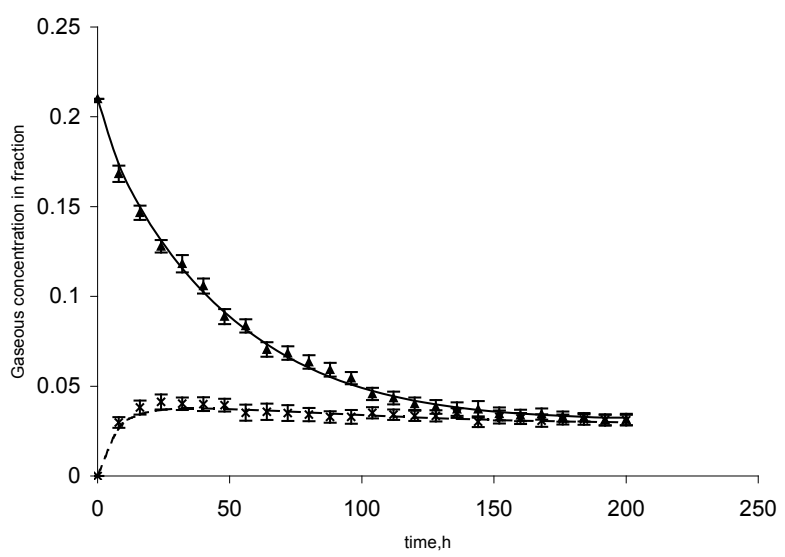

(b)

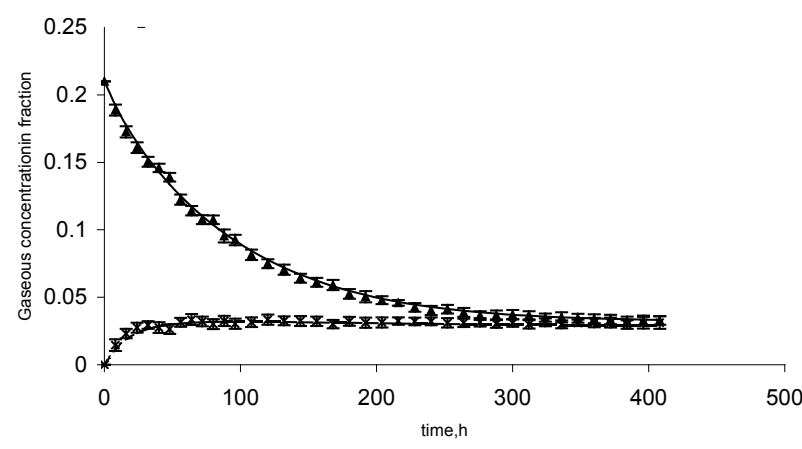

Figure 3: Gas exchange of packet containing $0.5 \mathrm{Kg}$ of Capsicum packaged under non perforated conditions at temperature of $5{ }^{\circ} \mathrm{C}$ and $15^{\circ} \mathrm{C}$. (a) is for measured $\mathrm{O}_{2}$ and $\mathrm{CO}_{2}$ concentration at $5^{\circ} \mathrm{C}$; (b) $\boldsymbol{\Delta}$ is for measured $\mathrm{O}_{2}$ and $\mathrm{CO}_{2}$ concentration at $15^{\circ} \mathrm{C}$. Error bar shows $( \pm)$ standard deviation. 
Citation: Pandey SK, Goswami TK (2012) An Engineering Approach to Design Perforated and Non Perforated Modified Atmospheric Packaging unit for Capsicum. J Food Process Technol 3:187. doi:10.4172/2157-7110.1000187

Page 4 of 4

(a)

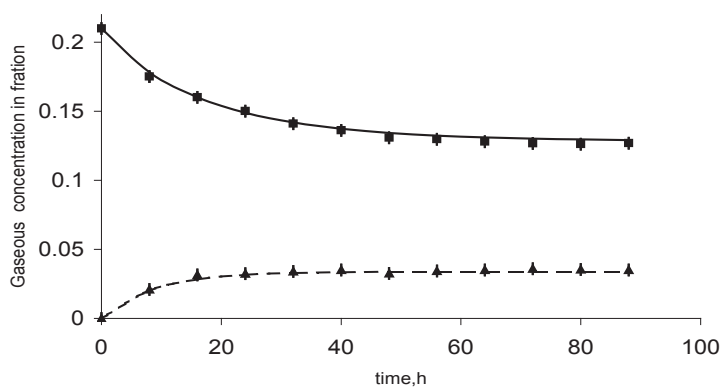

(b)

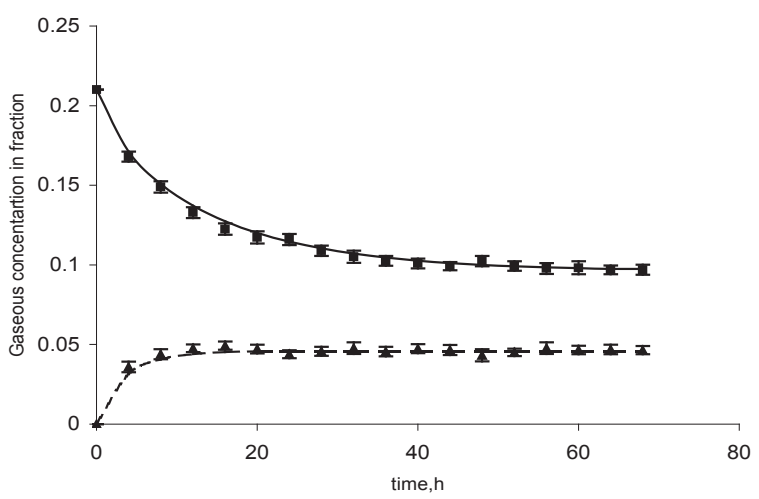

Figure 4: (a) and (b) Validation of model of packet containing $0.5 \mathrm{~kg}$ of capsicum under perforated condition at temperature 5 and $15^{\circ} \mathrm{C}$, respectively. (a) symbol denotes observed data for $\mathrm{O}_{2}$ concentration and $(\boldsymbol{\Delta})$ symbol for $\mathrm{CO}_{2}(-)$ solid line shows the predicted $\mathrm{O}_{2}$ and (--) shows predicted $\mathrm{CO}_{2}$ concentration. Error bar $\pm \mathrm{SD}$.

with constant mass and with constant diameter of hole resulted into higher $\mathrm{O}_{2}$ concentration and lower concentration of $\mathrm{CO}_{2}$. This is also evident from the Eqs. (5) and (6). Thus lower area was selected as it resulted into lower steady state concentration of $\mathrm{O}_{2}$ and higher $\mathrm{CO}_{2}$ concentration. Additionally, by varying the number of perforations, different gaseous in package steady state concentration could be obtained. Hence, size of packet was optimized for the dimension of $23 \times 23 \mathrm{~cm}$ for the storage study at the different temperatures in case of perforated conditions.

As stated earlier, perforation provides an alternative way to equilibrate with outside condition for high respiration produce. Retention of high relative humidity inside the package, reduction of $\mathrm{O}_{2}$ concentration and optimum rise of $\mathrm{CO}_{2}$ i.e. above $2 \%$ are the factors which contribute to the beneficial effects in MAP. Elevated $\mathrm{CO}_{2}$ (greater than $2 \mathrm{kPa}$ ) reduce the damaging effects of ethylene [12-13]. High in package relative humidity ensures the product hardness and less attack of microbes. Therefore, such system offers new opportunity for MAP of middle and high respiration produce in bulk and consumer packages in particular.

\section{Conclusions}

The Engineering approach is working, as the obtained equilibrium inside the packages is close to the predicted ones. Transient period was substantially less in case of perforated film compared to that for non perforated one. The effect of environmental temperature on headspace $\mathrm{O}_{2}$ level can be predicted. Macro perforation with high headspace $\mathrm{O}_{2}$ level, optimum $\mathrm{CO}_{2}$ concentration and high $\mathrm{RH}$ offer new possibility for middle and high respiration produce in bulk and consumer packages.

\section{References}

1. Lownds NK, Banaras M, and Bosland PW (1994) Postharvest water loss and storage quality of nine pepper (Capsicum) cultivars. HortScience 29: 191-193.

2. Smith DL, Stommel JR, Fung RWM, Whitaker BD (2006) Influence of cultivar and harvest method on postharvest storage quality of pepper (Capsicum annuum L.) fruit. Postharvest Biology and Technology 42: 243-247.

3. Cameron AC, Boylan-Pett and Lee WJ (1989) Design of modified atmosphere packaging systems: modeling oxygen concentrations within sealed packages of tomato fruits. Journal of Food Science 54: 1413-1415.

4. Exama A, Arul J, Leneki RW, Lee LZ, Toupin C, et al. (1993) Suitability of plastic films for modifies atmosphere packaging of fruits and vegetables. Journal of Food Science 58: 1365-1370.

5. Lakakul R, Beaudry RM, Hernandez RJ (1999) Modeling respiration of apple slices in modified atmosphere packages". Journal of Food Science 64: 105110.

6. González G, Tizado M (1993) Postharvest physiology of bell peppers stored in low density polyethylene bags. Lebensmittel Wissenschaft und Technologie 26: $450-455$.

7. González-Aguila GA, Cruz R, Baez R, Wang CY (1999) Storage quality of bell peppers pretreated with hot water and polyethylene packaging. Journal of food quality $22: 287-299$.

8. Srinivasa PC, Prasanth KVH, Susheelamma NS, Ravi R, Tharanathan RN (2006) Storage studies of tomato and bell pepper using eco-friendly films. Journal of the Science and Food and Agriculture 86: 1216-1224.

9. Manolopoulou H, Xanthopoulos G, Douros N, Lambrinos Gr (2010) Modified atmospheric packaging storage of green bell peppers: Quality criteria. Biosystem Engineering 106: 535-543.

10. Pandey SK, Goswami TK (2011) Modeling of Respiration Rate of Capsicum a Various Temperatures. International Journal of Food Engineering 7: 5.

11. Bhande SD, Ravindra MR, Goswami TK (2008) Respiration rate of banana fruit under aerobic conditions at different storage temperatures. Journal of food Engineering 87: 116-123.

12. Hener RC (1987) High $\mathrm{CO}_{2}$ effect on plant organs. In: J.Weichmann (Ed.). Post harvest Physiology of Vegetables. Marcel Dekker, New York p.239.

13. Kader AA, Zagory D, Kerbel EL (1989) Modified atmosphere packaging of fruits and vegetables. Crit Rev Food Sci Nutr 28: 1-30. 